\title{
Distance Education at the University of Dschang, Cameroon
}

\author{
Fedelis Lekeaka Alemnge \\ Faculty of Education, University of Buea, Buea, Cameroon \\ Email: alemngelekeaka@outlook.com
}

How to cite this paper: Alemnge, F. L. (2018). Distance Education at the University of Dschang, Cameroon. Creative Education, 9, 549-557.

https://doi.org/10.4236/ce.2018.93038

Received: February 1, 2018

Accepted: March 27, 2018

Published: March 30, 2018

Copyright (C) 2018 by author and Scientific Research Publishing Inc. This work is licensed under the Creative Commons Attribution International License (CC BY 4.0).

http://creativecommons.org/licenses/by/4.0/

\begin{abstract}
The Distance Education Project in Agriculture which began in 1990 at the University Centre of Dschang (UCD) was the fruit of collaboration between the University of Dschang, Cameroon and the University of Guelph, Canada and benefited from initial funding from the Canadian International Development Agency (CIDA). The programme effectively took off on 29 April 1996 with the publication of the Ministerial orders No. 00/003/MINESUP/DDES of 26/01/00 and No. 01/0040/MINESUP/DDES of 29/0501 related to the regime of studies and examination at the Distance Education Programme (DEP) and to the creation of the Centre for Distance Education (CDE) at the Faculty of Agronomy and Agricultural Sciences (FAAS) of the University of Dschang. This institutionalization of the DEP enabled the University to pioneer Distance Education in Cameroon Higher Education.
\end{abstract}

\section{Keywords}

Distance Learning, Agriculture, University of Dschang

\section{Introduction}

The University of Dschang (UD) is located in the town of Dschang. It is one of the 8 public universities of Cameroon. It was created by the reform of the university system in Cameroon by Decree No. 93/026 of 19 January 1993. It inherited the former University Center of Dschang (UCD), which was created by Presidential Decree No. 77/108 of April 28, 1977 with an agricultural vocation. The University has eight campuses in 6 of the 10 regions of the country. The institution has a student body of over 35,000 Cameroonian and foreign students. There are over 510 permanent teachers, and 583 support staff. The University of Dschang is committed to excellence in agricultural teaching, research and outreach. The ultimate goal is to make everyone who passes through this institution 
into the world to become more useful to themselves, their families and their country. Innovation is the cornerstone of the university and it was in this light that the Distance Education Programme came into being.

The idea of the programme was ignited by a chance visit of a staff of the University Centre of Dschang to the University of Guelph in Canada in 1988 after visiting the Independent Study Programme of the above University. He shared the information on return with the University Centre authorities and this led to the collaborative work between the University Centre and the University of Guelph which resulted in the proposal for a Diploma in Tropical Agriculture to be offered by the University Centre of Dschang in Cameroon by distance mode. The "Centre for Distance Education" (CDE) which is responsible for the execution of the programme is housed in the Faculty of Agronomy and Agricultural Sciences (FASA). The centre together with the regime of studies and examinations was sanctioned by the Ministerial Orders No 00/0003/MINESUP/DDES of 26/01/00 and No 01/0040/MINESUP/DDES of 29/05/01.

\section{Aim of the Programme}

The distance education programme was initiated in 1991 with funding from the Canadian International Development Agency (CIDA), and the collaboration of the University of Guelph, Canada with the aim of contributing to the national effort to offer adequate training to all those who want to acquire knowledge and practical skills while working "learning while they earn".

\section{Rationale}

The programme is based on the view that for Cameroon to move out of the traditional system of peasant agriculture into a dynamic, viable market-oriented and sustainable agriculture, it needed well trained and efficient middle-level staff. One of the ways this could be achieved lay in the democratization of learning through distance education programmes. The choice to pursue training by Distance Learning was motivated by the following considerations:

- The increasing demands on the government to offer agricultural training and education to its citizens;

- There was a group of agricultural technicians who had completed 2 or 3 years of training in either Dschang or the Regional College of Agriculture and needed opportunities for further professional growth in agriculture; and

- The prevailing system did not provide opportunities for people who desire further training in agriculture but could not leave their work or families for long periods of time. The programme also addressed the needs of special target groups such as women working at home, retired persons, looking for work and hobby farmers.

\section{Objectives}

The general objective is to provide access to the many Cameroonians who 
wanted university education in agriculture but could not get access into the Dschang University Centre because of limited access due to restrictive admission procedures and practices as well as lack of space and funds. The specific objectives are to:

- Upgrade the skills of people working in agriculture or those desiring to grow crops or raise livestock as a business;

- Develop an efficient and qualified pool of young men and women who could move Cameroon's agriculture forward based on a thorough mastery of science and technology;

- Provide adult education to people who would never get it because they cannot leave home or work for long periods of time for formal schooling elsewhere;

- Pave the way for sustainable distance education in Cameroon which can provide alternative means for easing the pressure on limited national educational resources (classrooms, equipment, personnel) at all levels; and

- Develop institutional capacity at the University of Dschang for the development and delivery of independent study programmes in Cameroon.

\section{Target Audiences}

The training programme targeted the following among others:

- Agricultural technicians with formal training; These are people who might have 2 or 3 years of post secondary training in general agriculture either at Dscahng or the Regional College of Agriculture.

- Field technicians without formal training in agriculture; These are people with a background in Mathematics, Biology, Chemistry and or Physics, who have a rich pool of working experience and are currently working at a research station without any formal agricultural training.

- Fulltime and Hobby Farmers are people who are either actively farming or practising some aspect of agriculture as a hobby.

- Persons with no agricultural background; These include school leavers and graduates looking for work and may want to venture into agriculture without any professional knowledge.

- Institutions or organisations that teach or practice agriculture; this group includes some privately owned and public secondary schools, Teacher Training colleges and other religious institutions. A course or two in agriculture by distance learning will add significant breadth to their training.

\section{Training}

Ten faculty members and one technician received short-term training in Canada in the areas of programme design, project administration, course development, audiovisuals and marketing. As a follow-up two workshops were organised in Cameroon between 1994 and 1995. These trainees ensured that the various courses of the programmes were well written locally. The pilot project was tailored 
to offer courses exclusively in agriculture to lead to various certificates and or diplomas in tropical agriculture. The hope was to extend the programme to other faculties of the university over time. The specially written course materials were supplemented with audio and video tapes, photograph prints, slides and text books where necessary.

\section{Learner Support}

Learner support was to be provided through the University's antennae at Maroua, Belabo, Ebolowa, Yaounde, Bambili and the facilities on the main campus at Dschang. Information was to be provided and practical work undertaken under supervision at these centres. Students who were to be working at their own farms were to be provided the needed orientation to enable them apply the knowledge gained from study of the courses to their specific situation and circumstances.

\section{Mode of Delivery}

The programme was to be carried out exclusively by post. Therefore students are advised to choose the most expeditious postal arrangement in their situation in order to minimize delays and curb frustrations.

\section{Registration}

Registration is open and strictly by means of the post office. Students are required to register in relation to their available resources, that is, time, money and equipment. Students interested in improving on their skills in a given area could register for the specific subject while others could either register for courses leading to a Certificate or Diploma depending on their interests. Registration is open throughout the year and students register at any time convenient to them

\section{Cost}

Students' admitted into the programme pay a registration fee of 5000frsCFA and purchase course material for each course at the cost of 15,000frsCFA. Beside these, students incur the cost of sending their assignments to the university and take care of their transport and lodging costs for the practical work sessions and the examination sessions. Students interested in using the antennae as mailing stations drop off their assignments at the office of the Chief of the Antenna after making proper arrangements.

\section{The Curriculum}

The programme is designed to offer courses leading to the award of either a Certificate or a Diploma in Tropical Agriculture in three different options:

$$
\begin{aligned}
& \text { Animal Science; } \\
& \text { Crop Science; and } \\
& \text { Agricultural Management. }
\end{aligned}
$$


Courses offered, Contact and Credit Hours and academic load

\begin{tabular}{|c|c|c|c|c|c|c|}
\hline \multirow{2}{*}{ CODE } & \multirow{2}{*}{ COURSE TITLE } & \multicolumn{3}{|c|}{ CONTACT HOURS } & \multicolumn{2}{|r|}{ CREDIT } \\
\hline & & LECTURE & PRACTICALS & TOTAL & HOURS & ACADEMIC WEIGHTING \\
\hline DE 01 AS & Animal Nutrition and Pastures & 60 & 30 & 90 & 06 & 02 \\
\hline DE 02 AS & Food Technology & 30 & 15 & 45 & 03 & 01 \\
\hline DE 03 AS & Pig Production & 30 & 15 & 45 & 03 & 01 \\
\hline DE 04 AS & Cattle, Sheep and Goat production & 90 & 30 & 20 & 08 & 03 \\
\hline DE 05 AS & Poultry and Rabbit Production & 60 & 30 & 90 & 06 & 02 \\
\hline DE 06 AG & Perennial Crops & 60 & 30 & 90 & 06 & 02 \\
\hline DE 07 AG & Food Crops & 60 & 30 & 90 & 06 & 02 \\
\hline DE 08 AG & Vegetable crops & 60 & 30 & 90 & 06 & 02 \\
\hline DE 09 SS & Applied Soil Science & 60 & 30 & 90 & 06 & 02 \\
\hline DE $010 \mathrm{CP}$ & Pest and Disease Management & 60 & 30 & 90 & 06 & 02 \\
\hline DE 011 GR & Irrigation and Drainage & 60 & 30 & 90 & 06 & 02 \\
\hline DE 012 GR & Crop Processing and Storage & 60 & 30 & 90 & 06 & 02 \\
\hline DE $013 \mathrm{RE}$ & Agricultural Extension & 30 & 15 & 45 & 03 & 01 \\
\hline DE $014 \mathrm{RE}$ & Applied Rural Sociology & 30 & 15 & 45 & 03 & 01 \\
\hline $\mathrm{DE} 015 \mathrm{AE}$ & Agricultural Economics & 70 & 20 & 90 & 06 & 02 \\
\hline $\mathrm{DE} 016 \mathrm{AE}$ & Credit and Finance & 30 & 15 & 45 & 03 & 01 \\
\hline $\mathrm{DE} 017 \mathrm{AE}$ & Farm Management & 60 & 30 & 90 & 06 & 02 \\
\hline $\mathrm{DE} 018 \mathrm{AE}$ & Agricultural Marketing & 30 & 15 & 45 & 03 & 01 \\
\hline $\mathrm{DE} 019 \mathrm{AE}$ & Project Analysis & 60 & 15 & 45 & 03 & 01 \\
\hline DE $020 \mathrm{FO}$ & Agroforestry & 60 & 30 & 90 & 06 & 02 \\
\hline TOTAL & & 1030 & 485 & 1515 & 101 & 34 \\
\hline
\end{tabular}

\section{Requirements for the Award of a Certificate}

To be awarded a Certificate for each of the above tracks students were required to take and successfully complete 3 required courses and 2 elective courses selected from two groups of courses provided.

The Animal Science Option previewed the acquisition of Certificates in; Ruminant production, Poultry and Rabbit production, and Pig production.

The Crop Science Option was supposed to enable students obtain Certificates in Food Crops, perennial crops production, and Horticulture.

The Agricultural Management track was to lead to the award of Certificates in Agricultural Finance, Agricultural marketing and Project analysis. 


\section{Requirements for the Award of a Diploma}

To be eligible for the award of a Diploma in Tropical Agriculture in any of the 3 tracks the student was required to have a pass in 12 required courses and 3 elective courses.

\section{Certificate and Diploma Awarded}

According to the Ministerial order the Diploma obtained at the end of the programme of study is the Diplomed' Etudes Universitaire professionelles en Agriculture (DEUP) (Diploma of Professional University Studies in Agriculture (DPUS) in Animal Production, Crop production or Agricultural Management. It is also possible to obtain Certificates in each of these options.

\section{Admission Conditions}

The training programmes of the $\mathrm{CDE}$ are open to all those who can read and write either French or English and want to acquire some knowledge. Those who seek to pursue the Diploma of Professional University Studies (DPUS) must be holders of the GCE Advanced Level, the Diploma of Agricultural Technician, or any other equivalent qualification.

\section{Duration of Training}

The training takes a minimum of 2 years and a maximum of 8 years since students are studying independently and at their own pace. If after 8 years a student has not completed the programmes/he can register and start all over as a new student.

\section{Opportunities after Graduation}

Students who successfully complete the Diploma programme are:

- Eligible to sit for the competitive entrance examination into the $3^{\text {rd }}$ year of FASA;

- If they are paid workers, solicit their reclassification by their employers;

- Gain admission into other national or foreign academic institutions;

- Get settled in their own farms;

- Look for jobs in NGO's and enterprises, working in the field of rural development;

\section{Organisation of Teaching}

\subsection{System of Study}

The system is based on correspondence and students enrol at any time they are ready and work at their own pace in completing the assignments, tutorials, practicals and final examinations.

\subsection{Tutorial}

There are two face-to-face tutorial sessions on campus each year. The first ses- 
sion takes place in March and the second session in August each year. Each session lasts for two weeks. The tutorials are dedicated to the registration of and orientation of all newly admitted students. During each session the course contents of the compulsory and elective courses are presented and any other valuable information concerning students' study is also provided.

It should be noted that tutorials involve field work, laboratory work as well as tutoring.

\subsection{Assessment}

The system of assessment includes: application exercises and self-evaluation at the end of every chapter of the course (with answers at the end of the manual); mailed in assignments practicals and tutorial reports and end of session examination. There are two end of session examinations each year and are held in March and September and each lasts two weeks.

Students are expected to submit from 2 to 4 assignments depending on the course. After successfully completing the required number of assignments for each course, the student is then eligible to sit for the end of session examination in either March or September as the case may be. Assessment is weighted as in Table 1.

To succeed in a module the student must have scored an average mark at least equal to $10 / 20$.

\subsection{Courses of the Programme}

The academic programmes are organised in Unit Values (U.V) or (Single Courses) which are further grouped into modules. These are taught in the form of individual reading of printed course materials accompanied by audiovisual materials such as audio and video tapes, tutorial, practicals in laboratories and in the field and internships.

There are 7 modules which constitute the common core courses of the three options of the programme (Animal production, Crop production and Agricultural management science). In addition to these common core modules is a specialised module for each of the three tracks.

Table 1. Assessment.

\begin{tabular}{ccc}
\hline Type of Assessment & \multicolumn{2}{c}{ Percentage } \\
\hline Course with tutorial & Course with no tutorial \\
Assignment & 30 & 40 \\
Practical \& Tutorial & 20 & -- \\
Examination & 50 & 60 \\
Total & 100 & 100
\end{tabular}


Common Core:

\begin{tabular}{|c|c|}
\hline \multicolumn{2}{|c|}{ MODULES } \\
\hline Module 1 & Module 2 \\
\hline MATH 0001-10 Applied Mathematics & VASR 0201-10 Applied Rural Sociology \\
\hline and Statistics & VASR 0202-10 Agricultural Extension \& \\
\hline CHEM 0002-100 Agricultural Chemistry & Rural Education \\
\hline PHYS 0003-100 Applied Physics & VASR 0203-10 Public Administration and \\
\hline BIOL 0004-10 General Biology & Agrarian Law \\
\hline Module 3 & Module 4 \\
\hline AGEC 0301-10 Agricultural Economics & SOSC 0401-10 General Soil Science \\
\hline AGEC 0302-10 Agricultural Credit & SOSC 0402-10 Applied Soil Science \\
\hline and finance & SOSC 0403-10 Irrigation \\
\hline AGEC 0303-10 Farm Management & SOSC 0404-10 Drainage \\
\hline AGEC 0304-10 Agricultural marketing & SOSC 0405-10 Agro forestry \\
\hline $\begin{array}{l}\text { Module } 5 \\
\text { AGRI 0501-10 Farm Practice } 1 \\
\text { AGRI 0502-10 Farm Practice } 2 \\
\text { VASR 0503-10 Monographic study report }\end{array}$ & $\begin{array}{l}\text { ANIMAL PRODUCTION OPTION: Module } 6 \\
\text { PRAN 0601-10 Animal Nutrition } \\
\text { PRAN 0602-10 Pastures } \\
\text { PRAN 0603-10 Food Technology I } \\
\text { PRAN 0604-10 Food Technology II }\end{array}$ \\
\hline $\begin{array}{l}\text { Module } 7 \\
\text { PRAN 0701-10 Pig Production } \\
\text { PRAN 0702-10 Cattle Production } \\
\text { PRAN 0703-10 Sheep \&Goats Production } \\
\text { PRAN 0704-10 Poultry Production } \\
\text { PRAN 0705-10 Rabbits Production }\end{array}$ & $\begin{array}{l}\text { Module } 8 \\
\text { AGRI 0801-10 Perennial Crops I } \\
\text { AGRI 0802-10 Perennial Crops II } \\
\text { AGRI 0803-10 Food Crops } \\
\text { AGRI 0804-10 Vegetable Crops }\end{array}$ \\
\hline CROP PRODUCTION OPTION: Module 9 & \\
\hline $\begin{array}{l}\text { CROP 0901-10 Pest Management in Tropical } \\
\text { Crops }\end{array}$ & $\begin{array}{l}\text { AGRICULTURAL MANAGEMENT SCIENCE: } \\
\text { Module } 10\end{array}$ \\
\hline CROP 0902-10 Disease Management in & AGEC 01001-10 Project Analysis I \\
\hline Tropical Crops & AGEC 01002-10 Project Analysis II \\
\hline CROP 0903-10 Crop Processing & VASR 01003-10 Peasant Organization \\
\hline
\end{tabular}

Studies presently lead to the Diploma of Professional University Studies (DPUS) in Agriculture (A level +2 years) in the following options:

Animal Production:

Certificate: required courses; Module 8 and 7

DPUS: REQUIRED COURSES; CC + Module 6

Crop Production:

Certificate: Modules 8 and $9+$ UV SOSC 0401-10 and 0402-10

DPUS: CC + Module 9

Management of Agricultural Enterprises:

Certificate: Modules 23 and 10

DPUS: CC + Module 10

Rural Engineering:

Certificate: Modules 1, 4 and 9

DPUS: NOT YET AVAILABLE 


\section{Administration}

The function 9ng of the Centre for Distance Education is assured by five structures. The Advisory Board is the consultative organ of the Centre. There is a Coordinator in charge of the daily management of the activities of the Centre, the services of the Registrar, of Research, Marketing and Cooperation and the Faculty. Lecturers of the CDE are designated by the Dean of the Faculty of Agronomy and Agricultural Sciences (FAAS) among permanent teachers in the Faculty upon recommendation by the Coordinator of the Centre. The CDE also call upon associate lecturers from other faculties of the University, academic and research institutions as well as specialist from the surrounding socio-professional milieu depending on their expertise.

\section{References}

CDE, LEARN WHILE YOU AARN. Information Flyer.

DEP (1996a). Distance Education at the University of Dschang. Bamenda: Gospel Press.

DEP (1996b). Distance Education Catalogue: Certificates and Diplomas in Tropical Agriculture from the University of Dschang. Bamenda: Gospel Press.

http://www.studengo.com/Home/UniversityDetails/57 (17/01/2018)

https://en.wikipedia.org/wiki/University_of_Dschang (18/01/2018) 